2

3

4

\title{
The Jiwozhai patch reef: A palaeobiodiversity hotspot in middle Givetian (Devonian) of South
}

China

Jiayuan Huanga, ${ }^{\mathrm{a}, \mathrm{b}}$, Kun Liang ${ }^{\mathrm{a}, *}$, Yue Wang ${ }^{\mathrm{c}}$, , Weihua Liao ${ }^{\mathrm{d}}$, Wen Guo ${ }^{\mathrm{d}}$, Stephen Kershaw ${ }^{\mathrm{e}}$ Juwan Jeon $^{\text {a,f }}$, Li Qiao ${ }^{\text {a }}$, Junjun Song ${ }^{d}$, Junye Ma ${ }^{\mathrm{a}}$, Yue Li ${ }^{\mathrm{a}}$, Bing Tu ${ }^{\mathrm{g}}$, Yang Tian ${ }^{\mathrm{g}}$, Yujue Wang ${ }^{\mathrm{a}, \mathrm{b}}$, Yao Wang ${ }^{\mathrm{a}, \mathrm{f}}$, Jiaxin Ma ${ }^{\mathrm{a}, \mathrm{b}}$, Mao Luo ${ }^{\mathrm{a}}$, Wenkun Qie ${ }^{\mathrm{a}, *}$

a State Key Laboratory of Palaeobiology and Stratigraphy, Nanjing Institute of Geology and Palaeontology and Center for Excellence in Life and Palaeoenvironment, Chinese Academy of Sciences, Nanjing 210008, China

${ }^{\mathrm{b}}$ University of Science and Technology of China, Hefei 230026, China

${ }^{\mathrm{c}}$ School of Resources and Environments, Guizhou University, Guiyang 550003, China

${ }^{\mathrm{d}}$ Nanjing Institute of Geology and Palaeontology, Chinese Academy of Sciences, Nanjing 210008, China

${ }^{\mathrm{e}}$ Department of Life Sciences, Brunel University, Kingston Lane, Uxbridge, UB8 3PH, United Kingdom

${ }^{\mathrm{f}}$ University of Chinese Academy of Sciences (UCAS), Beijing 100049, China

${ }^{\mathrm{g}}$ Wuhan Center of Geological Survey, China Geological Survey, Wuhan, 430205, Hubei, China

jyhuang@nigpas.ac.cn (Jiayuan Huang), kliang@nigpas.ac.cn (Kun Liang), gzyuewang@126.com (Yue Wang),weihualiao@163.com (Weihua Liao),wenguo@nigpas.ac.cn (Wen Guo), Stephen.Kershaw@brunel.ac.uk (Stephen Kershaw), nex2boy@naver.com (Juwan Jeon), liqiao@nigpas.ac.cn (Li Qiao), jjsong@nigpas.ac.cn (Junjun Song), jyma@nigpas.ac.cn (Junye Ma), yueli@nigpas.ac.cn (Yue Li), tbing502@126.com (Bing Tu),41834572@qq.com (Yang Tian), yujuewang@nigpas.ac.cn (Yujue Wang), yaowang@nigpas.ac.cn (Yao Wang),jxma@nigpas.ac.cn (Jiaxin Ma),maoluo@nigpas.ac.cn (Mao Luo),wkqie@nigpas.ac.cn (Wenkun Qie).

*Corresponding authors.

Abstract

This study is a detailed palaeontological and palaeoecological analysis of a middle Givetian (Middle Devonian) high-diversity patch reef located in a platform interior setting in South China. The location is Jiwozhai, Guizhou Province, in the Dushan Formation. A total of 83 species (including 23 undetermined species) belonging to 44 genera of reef organisms were identified, based on a detailed statistical analysis from 28 quadrats on the vertical section of the patch reef. The main reef builders are laminar and encrusting-behaviour stromatoporoids, laminar tabulate corals, and laminar or $<<$ Do you mean "and"? "Laminar" is a growth shape, "encrusting" is a type of substrate relationship; they are not compatible, so it cannot be "or". encrusting chaetetids, forming coverstones to build the reef framework, while abundant massive and branching tabulate corals and solitary rugose corals are also important for the formation of the reef by filling the spaces between the components of the coverstones. Reef dwellers including brachiopods, bryozoans, tubeworms, calcified cyanobacteria and gastropods, are only scarcely distributed in the Jiwozhai patch reef, having little impact on the distribution pattern. Consistent with the densely distributed species at Jiwozhai, complex ecological relationships, including extensive encrustations, spatial competition, and symbiosis have also been found among different organisms. The high palaeobiodiversity level of the Jiwozhai patch reef in platform interior emphasizes that understanding of species richness and diversity of functional groups in different habitats is critical for Givetian reef ecosystem reconstruction. Location of the patch reef in a platform interior may be the reason for the high diversity biota. The results from the Jiwozhai patch reef are evidence for a stable reef structure with evenly distributed major reef-frame builders and complex ecological relationships. The high level of species diversity is a common feature in South China, as well localities of many other palaeocontinents during the Givetian Period.

Key words: stromatoporoids, tabulate corals, biodiversity, ecological complexity, biotic interactions

\section{Introduction}

Devonian reefs are of great importance in understanding the evolutionary, palaeoecological and palaeogeographic patterns of marine animals in deep time (Kiessling et al., 2002). During the Middle 
Devonian Givetian stage, metazoan reefs reached an acme of the entire Phanerozoic (Copper, 2002; Copper and Scotese, 2003; Huang et al., 2019), manifested by vast scales, diverse reef complexes, as well as their geographic expansion to higher northern $\left(50^{\circ} \mathrm{N}\right)$ and southern latitudes $\left(50^{\circ} \mathrm{S}\right)$ (Kiessling, 2001; Copper, 2002; Jakubowicz et al., 2019). Middle Devonian reefs were particularly abundant, occupying large continental seaboard areas of carbonate platforms and vast inland epicontinental seas, including megareefs of the 1700-30 km long tracts of the Western Canada Sedimentary Basin, Canadian arctic (Innuitian platform), eastern Laurentia "Old Red Continent" (United Kingdom to Poland), eastern Russian Platform (northeast Laurentia), Ural "Fold Belt" (eastern slopes of Urals), Siberia, northwest Africa, and South China (Playford, 1980; Copper and Scotese, 2003). However, quantifying reef biodiversity has become a major concern, not only for understanding ancient analogues of modern reefs, but also for reconstruction of global diversity patterns and the relationships between environmental changes and biotic events.

As major reef-building organisms, Palaeozoic stromatoporoids and corals reached their highest diversity peak in the Middle Devonian Period during their entire evolutionary histories (Scrutton, 1997; Stearn, 2015), and have been the subject of extensive studies (e.g. Cook, 1999; Stadelmaier et al., 2005; Salerno, 2008; Kershaw et al., 2018). Also, chaetetids, bryozoans, ostracods, brachiopods, gastropods, crinoid and calcified cyanobacteria are common reef components in Givetian reefs, yet with less detailed work (May, 1991). Comprehensive studies of biodiversity and fossil compositions of Devonian reefs are essential for understanding Palaeozoic ecosystems. However, such works are relatively rare (e.g. Mistiaen, 1985; May, 1988, 1992; Geldsetzer et al., 1989; Hubert et al., 2007; Song et al., 1994; Kiessling, 2009), and most previous studies mainly focus on a single group of reef organisms.

In the South China Craton, Givetian reef complexes are widespread, with more than 60 reported reef sites across eastern Yunnan, southern Guizhou, Guangxi and Hunan provinces, forming a reef belt that extends over $1700 \mathrm{~km}$ (Wu et al., 2010). Although the biodiversity of Givetian reefs in South China is thought to be one of the highest worldwide, there have been few detailed studies on the reef organisms (e.g. Song et al., 1994; Liu et al., 2004). In this paper, we investigate the biodiversity of a Givetian patch reef at Jiwozhai, South China in detail, based on a quantitative quadrat survey. The aims of this study are: 1) to reveal species richness of a platform interior patch reef in the South China marginal sea; 2) to investigate the complex palaeoecological interactions between the reef organisms, thus improving our knowledge of Palaeozoic reefs during their maximum developments; and 3) to understand spatial structure and distributions of reef components in the Jiwozhai patch reef.

\section{Geological setting}

The South China Craton was located on the east of the Palaeo-Tethys Ocean and near the equator during the Givetian Period (Fig. 1A). The Guangxi (also known as Kwangsian) Orogeny that occurred in the Late Ordovician Period resulted in large-scale uplift and expansion of lands during Silurian to the Early Devonian time (Chen et al., 2010). South China drifted away from north Gondwana during $\sim 400-385 \mathrm{Ma}$ (Xian et al., 2019), and marine settings gradually developed in the southern part of South China due to intensified rifting and basement subsidence. In Givetian time, a large marginal sea was developed, leading to growth of an extensive carbonate platform, although this has a patchy distribution because of the formation of deep-water inter-platform basins (Fig. 1B). Middle Devonian marine deposits in South China Craton were divided by Hou et al., (1988) into four types, namely Qujing type (paralic facies), Xiangzhou type (benthic facies), Nandan type (pelagic facies) and transitional facies of the platform margin to upper slope. Xiangzhou type, in particular, is dominated by shallow-marine carbonate rocks yielding a rich benthic fauna of brachiopods, corals and stromatoporoids (Qie et al., 2019), and characterized by diverse Givetian reefs that are widely distributed in platform margins and interiors (Wu et al., 2010; Fig. 1B).

The Jiwozhai patch reef (GPS $25^{\circ} 50^{\prime} 56.12^{\prime \prime} \mathrm{N}, 107^{\circ} 34^{\prime} 32.74^{\prime \prime} \mathrm{E}$ ) developed in the lower part of the Jiwozhai (previously spelled Chiwochai) Member of the Dushan (previously Tushan) Formation in Dushan section, southern Guizhou (Fig. 1C, D). The Formation is subdivided into three members, the Jipao (previously Chipao), Songiiaqiao (previously Sunchiachiao) and Jiwozhai members in ascending order (Liao, 2003), and assigned to the Givetian Stage based on occurrence of brachiopod Stringocephalus, as well as the representative rugose coral Endophyllum-Sunophyllum-Argutastrea assemblage through this unit (Fig. 1D) (Liao, 2003). The Jiwozhai Member is composed mainly of 
dark-grey to black medium- to thick-bedded calcareous mudstone, muddy limestone and reef limestone in the lower part. It possesses a rich benthic fauna, including stromatoporoids, tabulate corals, rugose corals and brachiopods and others, described below. It has been interpreted as representing a shallowmarine environment in the platform interior along the southern margin of the Yangtze oldland (Liao, 2003). Previous palaeontological investigations concerned mainly stromatoporoids and rugose corals. Yang and Dong (1963) described 17 species of stromatoporoids, including widespread species, such as Stachyodes radiata, Hermatostroma episcopale, Paramphipora blokhini, Trupetostroma sublamellosum, Trupetostroma dushanense, and Actinostroma undulatum in the lower part of the Jiwozhai Member. Another systematic palaeontological work concerns rugose corals, and a total of 20 species were reported in the lower and upper part of the Jiwozhai Member (Liao and Birenheide, 1984, 1985; Birenheide and Liao, 1985). However, detailed and comprehensive studies on the Jiwozhai patch reefs are still lacking, except some pioneering work on the sedimentology, sequence stratigraphy, and general characteristics of the reefs (Wang et al., 2014; Wang, 2016).

\section{Materials and methods}

The studied patch reef is revealed in an exposure orientated east-west and located in the Dushan Dahekou geopark. The reef is not fully exposed, the part that is accessible is about $4.5 \mathrm{~m}$ thick and nearly $100 \mathrm{~m}$ wide (Fig. 2A). The patch reef is rich in fossils, accounting for $60 \%-80 \%$ of the carbonates (Fig. 2B-F), while limestones surrounding the patch reef are composed of thick-bedded bioclastic limestone with sparse fossils of corals and stromatoporoids. This study is based on detailed measurements of the Jiwozhai patch reef, including field observations of lithologies and sedimentary structures and sampling for microfacies analysis. Twenty-eight quadrats $(0.5 \mathrm{~m} \times 0.5 \mathrm{~m})$, occupying 7 $\mathrm{m}^{2}$ in total were selected from the vertical section of the patch reef (Figs. 2A, D; 3A, B) for quantitative analyses. The selected quadrats are representative of the entire patch reef structure. Fossil compositions of each quadrat were photographed and sampled in detail. Depending on fossil preservations in each quadrat, 15 to 45 samples per quadrat were collected to study the distribution patterns of reef components (Fig. 3C), and the sampled area was mapped in the field, with supporting photography. In total, 665 specimens were collected and analyzed. For a better identification of fossil species and investigation of microfacies, 2804 thin sections (including sets of serial sections), as well as eight polished slabs were also prepared for additional observations. The diversity and abundance of major fossil components, including stromatoporoids, rugose corals, tabulate corals, chaetetids, brachiopods, bryozoans, calcified cyanobacteria and tubeworms are counted based on the samples from the quadrats. For branching stromatoporoids and tabulate corals, we count only the relatively completed branches in an attempt to avoid an overestimation of the actual number. Nevertheless, we accept that branching stromatoporoids, as fragments, are difficult to quantify so our estimate of those components is less precise than non-branching forms. Distribution of the fossil components and reef structure is realized by detailed counting of the thin sections and slabs, as well as broad identification of fossil types from the field photos over the vertical section of the patch reef. Fossil components and diversity of each quadrat are illustrated in detail, and the variation among the quadrats is also evaluated by comparing the accumulating number of genera and species from the first quadrat to the last. All fossil specimens are deposited in the Nanjing Institute of Geology and Palaeontology, Chinese Academy of Sciences, Nanjing, China.

\section{Fossil components of the patch reef}

The Jiwozhai patch reef represents a biodiversity hotspot in South China marginal sea near the palaeoequator during the Givetian Period, recording 83 species belonging to 44 genera of 8 phyla reef organisms that identified from the 28 quadarts of the Jiwozhai patch reef (Fig. 4A). Among them, rugose corals, tabulate corals, stromatoporoids, chaetetids, and brachiopods are relatively more abundant in number, while other benthic fossils such as bryozoans, calcified cyanobacteria, crinoids, gastropods, etc. are relatively scarce in the reef community. All the reef organisms identified in this study are described below according to their importance with respect to the reef-forming process.

\subsection{Stromatoporoids}


Stromatoporoids, the most important reef-forming organisms in the Jiwozhai patch reef, are highly of the stromatoporoids range from 20 to $40 \mathrm{~cm}$ in width, but some much larger ones exceed $50 \mathrm{~cm}$. Their sizes are on average, much larger than any other reef contributor in the Jiwozhai reefs. The most abundant genus is Clathrocoilona $(\mathrm{N}=270$; Fig. 4B). Next, Trupetostroma $(\mathrm{N}=149)$, Stachyodes $(\mathrm{N}$ $=111)$, Actinostroma $(\mathrm{N}=99)$, and Stictostroma $(\mathrm{N}=98)$ are also quite common, while Stromatopora $(\mathrm{N}=9)$, Salairella $(\mathrm{N}=8)$, Habrostroma $(\mathrm{N}=7)$, Synthetostroma $(\mathrm{N}=3)$ and Parallelopora $(\mathrm{N}=1)$ appear relatively sparsely (Fig. 4B). This distribution of taxa, with 2 or 3 taxa being very abundant, and others less so, is characteristic of stromatoporoid assemblages in the Palaeozoic (Kershaw et al., 2018). Stromatoporoids in the patch reef exhibit laminar and dendroid forms, and encrusting behaviours. As the main reef constructors, the ratio of width to height of laminar stromatoporoids is generally over 10 . Among them, Trupetostroma dushanense $(\mathrm{N}=128$; Fig. 5G) and Actinostroma undulatum $(\mathrm{N}=99$; Fig. $5 \mathrm{~A}$ ), both possessing long and continuous pillars much thicker than their laminae, are the most abundant species. Many of the laminar stromatoporoids show conspicuous latilaminae inside the skeletons (Fig. $5 \mathrm{~A}, \mathrm{~B}, \mathrm{G})$. The frequent sediment influx and settlement of calcified cyanobacteria on the surface of the stromatoporoid skeletons appear to be regular, and may be seasonal, indicating a higher depositional rates than the growth of the stromatoporoids which cause the cease of growth of the stromatoporoids. However, the laminar stromatoporoids recovered quickly and continued to grow (Fig. 5A, B, G). Also, the encrusting-behaviour stromatoporoids are important reef builders, often found to be associated with solitary rugose corals, tabulate corals, chaetetids and bryozoans (Fig. 5B, H). Clathrocoilona and Stictostroma are the most abundant encrusting-behaviour genera (Fig. 5B, C, E). In addition, dendroid stromatoporoids belonging to species of Stachyodes (Fig. 5E) occur in the patch reef in a variety of orientations, but are more common in the upper part. They are less important than the laminar and/or encrusting-behaviour stromatoporoids.

\subsection{Tabulate corals}

As important reef builders, the tabulate corals show a diverse assemblage with 8 genera and 13 species $(\mathrm{N}=630$; Fig. 4A, B) and possess various growth forms. Thamnopora $(\mathrm{N}=303)$ is the most common one, followed by Crassialveolites $(\mathrm{N}=101)$, Cladopora $(\mathrm{N}=68)$, Roseoporella $(\mathrm{N}=57)$, Aulopora $(\mathrm{N}=42)$, and Scoliopora $(\mathrm{N}=39)$, while Alveolites $(\mathrm{N}=10)$ and Syringopora $(\mathrm{N}=10)$ are relatively scarce (Fig. 4B). Branching tabulate corals are commonly $15-40 \mathrm{~cm}$ in height and $2-13 \mathrm{~mm}$ in diameter. Thamnopora $\mathrm{cf}$. pansiensis $(\mathrm{N}=236$; Fig. $6 \mathrm{H})$ and Thamnopora compacta $(\mathrm{N}=50$; Figs. $6 \mathrm{G})$ are predominant, while Cladopora fistula $(\mathrm{N}=68$; Fig. $6 \mathrm{~K}, \mathrm{~L})$ is less abundant. Most specimens of branching species are found to be toppled and fragmented, commonly distributed in the matrix between the reef frameworks, while some are encrusted by stromatoporoids or chaetetids (Fig. 5H, 6G), or served as hard grounds for growth of other organisms. Compared with branching tabulates, the massive tabulate corals, including species of Alveolites and Crassialveolites (Fig. 6I, J), Roseoporella all of which range from laminar to domical growth forms, are slightly less abundant in number. Other taxa that occur rarely in the Jiwozhai patch reef include tabulate corals with reptant growth style (whereby the coral tubes grew horizontally along the substrate) include species of Aulopora and the early growth stages of Syringopora. Species of Aulopora commonly used the surface of dead laminar stromatoporoids or chaetetids as substrate, while Syringopora began growth on surfaces of stromatoporoids assumed to have been alive when Syringopora settled. Syringopora tubes then became endosymbionts of stromatoporoids, in two taxa, Stromatoporahüpschii (Fig. 5F) and Trupetostroma cf. colliculosum. There is likely to have been a biological symbiotic relationship between Syringopora and those two stromatoporoid taxa. No free forms of Syringopora are observed in this reef.

\subsection{Chaetetid sponges}

Chaetetid sponges are also important skeletal reef builders, but only one species, Litophyllum inflatus is found ( $\mathrm{N}=144$; Fig. 4A, B), much less diversified than the corals and stromatoporoids in the Jiwozhai reefs. The species exhibit laminar to low domical growth forms of 1-4 mm in height (Fig. 5A, 
214 I) or encrusting other organisms (Figs. 5H, 6G), forming the reef framework together with 215 stromatoporoids and corals.

\subsection{Rugose corals}

At specific level, rugose corals are the most diverse reef organisms in the Jiwozhai patch reef (9 genera, 29 species; $\mathrm{N}=198$; Fig. 4A, B). Among the genera, solitary rugose corals are predominant, including Sinodisphyllum $(\mathrm{N}=67)$, Pseudozaphrentis $(\mathrm{N}=35)$, Temnophyllum $(\mathrm{N}=28)$, Mictophyllum $(\mathrm{N}=26)$, Sunophyllum $(\mathrm{N}=16)$, and Cystiphylloides $(\mathrm{N}=11)$, while fasciculate and cerioid rugose corals are rare, including Disphyllum $(\mathrm{N}=11)$, Arguastrea $(\mathrm{N}=2)$, and Thamnophyllum $(\mathrm{N}=2$; Fig. 4B). The solitary rugose coral species are represented by Sinodisphyllum simplex (N=25; Fig. 6B), $S$. litvinovitshae $(\mathrm{N}=22)$, S. variable $(\mathrm{N}=15)$, Pseudozaphrentis hejiazhaiense $(\mathrm{N}=35$; Fig. $6 \mathrm{~A})$, Temnophyllum poshiense $(\mathrm{N}=10)$ and Mictophyllum cf. shawoziense $(\mathrm{N}=15)$, of which the diameter ranges commonly from 1.2 to $2 \mathrm{~cm}$. Large solitary rugose corals are extremely rare, represented by Cystiphylloides corneolum $(\mathrm{N}=2$ ), which is up to $6 \mathrm{~cm}$ in diameter (Fig. $6 \mathrm{~F}$ ). A significant number of solitary rugose corals was encrusted or intergrown with stromatoporoids or chaetetid sponges (Fig. 6A; free-living solitary rugose corals are horn-shaped, mostly living on matrix between the reef frameworks. Apart from the abundant solitary rugose corals, fasciculate rugose corals, represented by Disphyllum intermedium $(\mathrm{N}=9)$ and Thamnophyllum sinense? $(\mathrm{N}=2)$, are found to be toppled and fragmented in most cases, while cerioid rugose corals, represented by Argustarea thomasi $(\mathrm{N}=2$; Fig. 6C) are in growth position. Although fasciculate and cerioid rugose corals are reef-frame builders, they are scarce and not significant for the reef-forming process of the Jiwozhai patch reef.

\subsection{Brachiopods}

Brachiopods are highly diverse in both generic and specific levels ( 8 genera, 16 species; $\mathrm{N}=84$; Fig. 4A, B). Athyris and Emanuella, each possessing 4 species, are more diversified than the other genera (Fig. 7C, D). The majority of the brachiopods in the patch reef are quite small-sized, with a width ranging from 5 to $10 \mathrm{~mm}$. The most common species is Leiorhynchus sp. A $(\mathrm{N}=51$; Fig. 7A), followed by Athyris sp. A ( $=8$; Figs. 7C), Howittia dushanensis $(\mathrm{N}=5$; Figs. 7B), and Ambothyris sp. $(\mathrm{N}=5)$. Some brachiopods grow on the surfaces of laminar stromatoporoids or tabulate corals, and were occasionally buried after death by growth of stromatoporoids (Fig. 8E). The typical Givetian brachiopod Stringocephalus, which is a giant brachiopod that occurs commonly in the Dushan Formation, has not been found in the Jiwozhai patch reef, suggesting unfavourable habitats for these large-sized brachiopods.

\subsection{Bryozoans}

Bryozoans in the Jiwozhai patch reef are of low-diversity and rare (4 genera, 4 species; $N=19$; Fig. 4A, B). They are variable in growth forms, ranging from domical, laminar to branching. Fistuliporella hemispheroidea is the most common species $(\mathrm{N}=16)$, often encrusting other organisms (Fig. 8F). The domical bryozoans have a width up to $40 \mathrm{~mm}$ (Fig. 7E), while small branching ones are only $1 \mathrm{~mm}$ in diameter, dwelling on the soft substrate in the reef matrix, and often found to be fragmented.

\subsection{Tubeworms}

One species of tubeworms, Torquaysalpinx sokolovi $(\mathrm{N}=42$; Fig. 4A, B), is frequently found embedded in the skeletons of stromatoporoids, tabulate corals and chaetetids (Figs. 5I, 7G, H), yet no free-living ones are found, suggesting an endosymbiotic relationship. Torquaysalpinx sokolovi is usually round or elliptical in transverse view, with diameters ranging from 1 to $2 \mathrm{~mm}$. The tube walls are relatively thick and spiraling-shaped upward (Fig. 7G), comparable to those described by Zapalski and Hubert (2011). Dissepiments are occasionally observed inside the tubes (Fig. 7H). Judging from the non-curved growth band near the tubeworms (i.e. laminae in stromatoporoid, tabulae in chaetetid), the growth of stromatoporoids and chaetetids was generally not affected by the species, similar to the endobiont corals. 
Calcified cyanobacteria are of low-diversity, rare and not significant in the Jiwozhai patch reef. Rothpletzella-like microbe, and Fig. 7K more closely resembles Hedstroemia, which is fan-shaped or hand-shape illustrated containing continuously bifurcated filaments of 50 to $80 \mu \mathrm{m}$ in diameter (Fig. $7 \mathrm{~K}$ ), is identified from the patch reef. The specimens have much larger filaments than those reported from the Silurian of Gotland (Wood, 1948), but similar to those of the Upper Devonian strata of Russia (Zatoń and Jarochowska, 2018). Besides, a few specimens of Girvanella are also found to occur, but only from one quadrat, evidence of limited distributions of the organism. The calcified cyanobacteria commonly grew on the surface of stromatoporoid skeletons, indicating growth interruption of the stromatoporoids. Ordovician calcimicrobe associations in Tarim Basin were interpreted by Liu et al. (2016), to be common in environments that are partly restricted, such as lagoonal and back-reef facies, discussed later.

\subsection{Other fossils}

Ostracods, gastropods, nautiloids, echinoderms occurred sporadically in the patch reef (Fig. 7F, I, L). Under the microscope, the ostracods (Fig. $7 \mathrm{~L}$ ) are about $0.7 \mathrm{~mm}$ in length and commonly co-occur with gastropods. They are reef-dwelling organisms of the reef community. Only one nautiloid fragment (Fig. 7F) is observed in quadrat 14. In addition, plenty of crinoid stems fragments are also found to occur, indicating the existence of these reef-dwelling organisms in the Jiwozhai reef.

\section{Ecological complexity}

Prior to the Frasnian-Famennian mass extinction, metazoan reefs are composed of ecologically interacting species and characterized by various types of symbiotic interactions between different organisms during Early and Middle Devonian time (Vinn, 2016; 2017). Although the Jiwozhai reef represents a small patch reef that existed in the platform interior along the Yangtze oldland, which is generally considered to be a relatively unfavourable habitat with high turbidity and soft substrate, complex ecological relationships are found to occur in all 28 quadrats. The biotic interactions between different reef contributors are mainly manifested as extensive encrustations, spatial competition, and symbiosis. The abundance of fossils and the complexity of interactions identified in this study are evidence that the environment was favourable to the organisms found as fossils.

The most conspicuous ecological feature in the Jiwozhai patch reef is the extensive encrustation by species of stromatoporoids Clathrocoilona crassitexta, C. obliterata, C. spissa, Stictostroma saginatum, and chaetetids Litophyllum inflatus, occurring in a total of 716 cases observed in the majority of collected samples. These encrusting-behaviour stromatoporoids and chaetetids have flexible growth strategies, and their growth forms vary greatly from one species to another and flexibly changed under different environmental conditions. The encrusting behaviour is more or less opportunistic, commonly over dead skeletons (Figs. 5B, E, G; 6A, G; 8A, B, F), but there is evidence in Fig. 8C, D that stromatoproids could grow over living organisms. A growth sequence of multiple encrustations by stromatoporoids, tabulate corals, and/or chaetetid is commonly observed (Figs. 5H; 6J; 8A, D, F), forming rigid boundstones important for the formation of reef frameworks.

Due to the densely packed skeletons, competition for growth space is commonly found to occur, between: different stromatoporoid taxa; stromatoporoids and corals; stromatoporoids and chaetetids; stromatoporoids and bryozoa; and chaetetids and corals. A total of 35 cases of competition was observed in the suite of 2804 thin sections (Table 1). Live-live competitive behaviour is demonstrated by the growth deformity of the organisms and their direct contacts (Fig. 8C, D). Competitive intergrowths between these co-occurring species possibly indicate competition for favorable substrates between the benthic organisms. It is estimated that the actual spatial competition between the reef organisms must be much more than the counted number. The fact that all the observed cases involve either stromatoporoids or chaetetids, or both, is intepreted here as evidence that hypercalcified sponges are more active in occupying spaces in the patch reef.

Endosymbiotic intergrowth occurs between tabulate coral Syringopora and stromatoporoid Stromatopora hüpschii $(\mathrm{N}=9$; Fig. $5 \mathrm{~F})$ and Trupetostroma cf. colliculosum $(\mathrm{N}=1)$; no free-living Syringopora is observed, suggesting the growth of syringoporoid corals relies on stromatoporoids. Another symbiotic relationship involves tubeworms $(\mathrm{N}=48$; Figs. 5I, 7G, 7H) embedded within the 
skeletons of stromatoporoids Actinostroma undulatum, Stromatopora hüpschii, and Trupetostroma dushanense, tabulate coral Roseoporella sp. A, Roseoporella sp. B, Scoliopora sp., and Alveolites stenoporides, and chaetetids Litophyllum inflatus. In contrast to syringporoids, the tubeworms have been interpreted as parasites to the host organisms (Tapanila, 2005; Zapalski and Hubert, 2011). In addition, rare brachiopod shells of unknown species are found to be associated with the stromatoporoid Stromatopora, and there may have been syn-vivo interactions between the two organisms (Fig. 8E), although this is difficult to prove. These cases suggest that symbiotic relationships or syn-vivo interactions occur commonly due to the high density and diversity of benthic organisms.

\section{Spatial distributions of the reef community}

From detailed mapping of components of the Jiwozhai patch reef (Fig. 9), it is clear that the patch reef is slightly inclined towards its margin, containing abundant stromatoporoids, tabulate corals, and chaetetids, and rugose corals that are densely packed as the main reef builders. For major reef-frame builders, the Jiwozhai patch reef is characterized as Actinostroma-Clathrocoilona-ThamnoporaCrassialveolites ecological community. Following the classification of reef limestones by Flügel (2010), the framework of Jiwozhai patch reef is predominantly composed of coverstones, framestones and bafflestones (Figs. 2B-D; 3B, 9). The coverstones are carbonate rocks dominated by in-situ tabular or lamellar organisms covering, protecting and stabilizing broken debris, and was included by Embry and Klovan (1971) as a part of bindstone category. The coverstones in the present study are composed of abundant laminar (several to tens centimeters in basal length) stromatoporoids, tabulate corals, chaetetids that are mostly in growth positions, covering smaller bioclasts and matrixes and stabilizing unconsolidated sediment on the seafloor (Fig. 2B-F). These laminar fossils usually have undulated bottoms; although their width and thickness are highly variable, the ratio of width to thickness is commonly more than 10 . In general, they are distributed unevenly among the 28 quadrats and more abundant in the upper part of the patch reef (Fig. 9). Less abundant in the number of occurences, massive tabulate corals and branching tabulate corals, and solitary rugose corals densely filled the spaces between the coverstones, forming framestones and bafflestone to build the patch reef (Fig. 9). The massive tabulate corals that filled the spaces are mostly in growth position, while branching tabulate corals and solitary rugose corals are in a variety of orientations, and more common in the lower part of the patch reef (Fig. 9). The branches of tabulate corals are potentially wave-resistant, supplying spaces for depositions of smaller intraclasts. Also, the matrix between the coverstones is composed of dolomitic lime-muds and micro-calcite<<do you mean "micrite"? If not then please state clearly what is micro-calcite. containing various reef dwellers including brachiopods, gastropods, nautiloids, echinoderms, etc.

Although the generic and specific level diversities of reef organisms fluctuate among different quadrats, the major reef frame builders, including stromatoporoids, tabulate corals, and chaetetids are quite evenly distributed (Fig. 10A, C), as there are no distinct diversity changes by accumulating the genera and species numbers of the 28 quadrats (Fig. 10B, D). Stromatoporoids Actinostroma undulatum, Trupetostroma dushanense, Clathrocoilona crassitexta, C. obliterata, C. spissa, Stachyodes costulata, S. radiata, Stictostroma saginatum and tabulate corals Crassialveolites dushanensis, Thamnopora cf. pansiensis, Cladopora fistula, Scoliopora sp., Roseoporella sp. A, Aulopora cf. compacta are common reef constructing species that occur in all quadrats. The distributions of rugose corals and brachiopods, however, changes significantly among the quadrats, as judged by the obvious increase of generic and specific level diversity by accumulating the quadrats (Fig. 10B, D). Brachiopods occur more commonly in the middle and upper part of the patch reef, while rugose corals are more abundant in the lower part, serving as hard grounds for the growth of reef-frame building organisms. Other fossil groups, including tubeworms, bryozoans, calcified cyanobacteria and gastropods, are only sparsely distributed in the Jiwozhai patch reef. They do not have impacts on the distribution pattern due to low species richness and abundances.

Thus, distribution of components of the Jiwozhai patch reef (Fig. 9), using quadrat measurements to assemble data, gives evidence for a relatively stable reef structure, with laminar and encrustingbehaviour stromatoporoids and chaetetids, and laminar to low domical tabulate corals as main reefframe builders, while massive tabulate corals, branching tabulate corals, solitary rugose corals, and other subordinate organisms filled the spaces between the coverstones. Such a mode is also found in 
the other patch reefs of the Dushan Formation at Jiwozhai (Fig. 2B-D). In addition, the reef-frame builders are evenly distributed, while significant variations occur among the subordinate reef builders and reef dwellers.

\section{Comparisons with other Givetian reefs}

A number of Givetian reefs occur in South China Craton, such as the platform-margin reefs from Buzhai, Maoying of Guizhou Province and Liuzhai, Beishan and Yanshan from Guangxi Province, biostromes of the Qiziqiao Formation from Hunan Province (Dong et al., 1989; Liu and Dong, 1991; Mao and $\mathrm{Wu}, 1995$; Shen and $\mathrm{Yu}, 1996$; Liu et al., 2000; Liu et al., 2004). The platform-margin reef complexes at Buzhai and Liuzhai are all of large size, and 604, 129.5, 667 meters in thickness, respectively, much thicker than the Jiwozhai patch reef. They are built mainly by stromatoporoids Actinostroma, Stromatopora, Clathrocoilona, Trupetostroma and Ferestromatopora, and tabulate corals Thamnopora, Alveolites, and Crassialveolites, more or less similar to the major reef constructors of the Jiwozhai patch reef. However, the stromatoporoids in these platform-margin reefs are mostly domical forms (Liu and Dong, 1991; Liu et al., 2004), forming reef frameworks directly against highenergy environments. In addition, fasciculate and cerioid rugose corals, and brachiopod Stringocephalus are also more abundant in these reefs, but the diversity of solitary rugose corals is considerably less than that of the Jiwozhai patch reef. It is noteworthy that species of Amphipora are commonly found in the lagoon facies of these reef complexes, yet not a single skeleton is observed in the Jiwozhai patch reef. Liu et al. (2016) noted that calcimicrobe associations including Rothpletzella and Hedstroemia taxa (present in the Jiwozhai samples) are indicative of some measure of restricted environments, that might apply to the Jiwozhai reef setting. The lack of the stromatoporoid taxon Amphipora in Jiwozhai is unusual. Amphipora is ubiquitous in Devonian reef systems and its absence in Jiwozhai may reflect some environmental differences compared to platform margin reefs in other Devonian examples.

Compared with the platform-margin reefs of South China, the Jiwozhai patch reef possesses more diverse rugose and tabulate corals in both genus and species level, but similar in the diversity level of stromatoporoids. 15 species that occur both in the platform-margin reefs and the present patch reef are stromatoporoids Clathrocoilona crassitexta, Clathrocoilona obliterata, Synthetostroma actinostromoides, Stromatopora hüpschii, Habrostroma laminosum, Parallelopora ostiolata, Stachyodes costulata, Stachyodes radiata, tabulate corals Thamnopora cf. pansiensis, Cladopora fistula, rugose corals Temnophyllum waltheri, Temnophyllum poshiense, Sinodisphyllum simplex, Sinodisphyllum variable, Sunophyllum typicum, whereas most other species are restricted to more open environment (e.g. Stringocephalus).

In central Hunan, Liu et al. (2000) reported six types of reef assemblages in the Givetian biostromes of the Qiziqiao Formation by differences of the major reef-frame builders, including a) irregular forms of stromatoporoids Actinostroma, Stromatopora, Clathrodictyon, Stromatoporella and massive rugose coral Argutastrea; b) domical corals Argutastrea and Endophyllum and stromatoporoids Stromatopora, Gerronostroma, and Paralellopora, c) branching tabulate corals Thamnopora and encrusting-behavior stromatoporoids Clathrocoilona, d) small and high domical stromatoporoids Trupetostroma, Actinostroma, and Clathrocoilona, and tabulate corals Alveolites and Thamnopora, e) thin laminar stromatoporoids Clathrocoilona, Trupetostroma, and Stromatopora, and f) biostromes built by calcified cyanobacteria. Compared with the biostromes of the Qiziqiao Formation, the Jiwozhai patch reef is a combination of types $\mathrm{C}$ and $\mathrm{E}$ of the types recognized by Liu et al. (2000), and reef organisms are more densely packed, with very few domical stromatoporoids, and the calcified cyanobacteria are not significant reef builders. The differences among the reef types are mainly controlled by the different depositional environments (Liu et al., 2000). Similar classifications of the types of Middle Devonian reefs have also been described in Europe (Burchette , 1981; Fernandez-Martinez et al., 1994), suggesting cosmopolitian features in Middle Devonian reefs. The Jiwozhai patch reef is located within the platform interior, with muddy substrates and periodical high-energy environments, resulting in the dominance of laminar stromatoporoids, tabulate corals, and chaetetids as main reef constructors. Zapalski et al. (2017) noted the dominance of platy tabulate and rugose corals in two Middle Devonian localities in the Holy Cross Mountains, Poland and interpreted photosymbiosis in those corals. In the Jiwozhai patch reef, not only tabulate corals, but abundant stromatoporoids and chaetetids exhibit platy growth habits similar to 
those of the corals, and their growth forms may be affected by light availability, as well as the influence of soft substrates and periodical high energy enents such as storms. The biodiversity level and intensive biotic interactions in the Jiwozhai patch reef are higher than previously reported reefs in South China, which is interpreted here to indicate that the platform interior reef was a biodiversity hotspot for the reef organisms.

We repeat a key point made earlier in this study, that the Devonian Period witnessed the most remarkable reef-building episode in the Phanerozoic, and particularly, stromatoporoid-coral reefs reached a climax during the early to middle Givetian (Copper, 2002), and distributed globally in low latitudes, extending even to higher latitudes (Kiessling, 2001; Jakubowicz et al., 2019). Metazoan reefs built mainly by stromatoporoids and tabulate and rugose corals were quite common in many other localities around the world, such as the lower Givetian coral limestones of Rhenish Massif (35 species of 33 genera, major reef builders include stromatoporoid Stictostroma, Clathrocoilona and tabulate coral Alveolites; May, 1992), Horn Plateau reefs in Canada (76 species, major reef builders include tabulate coral Alveolites, Favosites, Thamnopora, rugose coral Atelophyllum, Australophyllum, Hexagonaria, and stromatoporoid Trupetostroma, Stromatopora; Vopni and Lerbekmo, 1972), and Aferdou el Mrakib reefs in Morocco (46 species of 36 genera, major reef builder tabulate coral Heliolites, Favosites, rugose corals Phillipsastrea, Endophyllum, Thamnophyllum, and stromatoporoid Stromatoporella, Actinostroma; Jakubowicz et al., 2019). Although the reef-building organisms varied among different reef sites, it is apparent that the laminar growth forms of reef-building organisms including stromatoporoids and tabulate corals are a common feature of the Givetian communities and widespread on different palaeocontinents. On the other hand, biotic interactions, including encrustations, spatial competition, and various forms of symbiosis among these metazoan reefs are a common feature and occur frequently (May, 1992; Zhen and West, 1997), which plays an important role in the reefforming process. The frequency of biotic interactions seems to reach a climax as well, in accordance with the magnificent scale of the Givetian reefs.

Detailed mapping of the Jiwozhai patch reef reveals remarkably high species-level biodiversity, adding to information about the complexity of reef ecological relationships, resulting in a stable reef ecosystem that is widespread in South China as well as many other localities of the world during the Givetian times. More detailed studies in terms of fossil components and ecological relationships on other reefs from South China as well as other palaeocontinents are necessary, for a better understanding of the biodiversity level and evolution of reef in deep time.

The reef system appears to have reached a mid-Palaeozoic maximum in the Middle Devonian Period, with cumulative thicknesses and sizes expanding in the late Eifelian and peaking especially in early to middle Givetian time (Copper, 2002). The major metazoan reef builders, including stromatoporoids, tabulate corals and rugose corals, attained their maximun genus-level diversity during the Eifelian (Scrutton, 1997; Stearn, 2015). However, in species-level diversity, the scenario might be different, as has been shown in the Devonian of Ardennes (Belgium), where maximum diversity appears in the Givetian (Zapalski et al., 2007). Mega-reef belts over $1000 \mathrm{~km}$ were widespread to a global scale in Middle Devonian and the Givetian marks the peak of Devonian reef distrubtion and carbonate platform growth, following progressive expansion of metazoan reef from the Emsian onward (Copper and Scotese, 2003), which corresponds to the increasing diversity level of major reef building organisms. This study on the Jiwozhai patch reef adds to the evidence that high species diversity level and complex ecological relationships between reef organisms is a common feature of Middle Devonian reefs and closly related to the development of the vast-scale reef belts.

\section{Conclusions}

1. A total of 83 species (including undetermined species) belonging to 44 genera of eight different reef organisms were identified in Jiwozhai reef, Dushan Formation, South China, representing a high level of species biodiversity. Among them, rugose corals are the most diverse in specific level (29 species of 9 genera), followed by stromatoporoids (16 species of 10 genera), brachiopods (16 species of 8 genera), tabulate corals (13 species of 8 genera), bryozoans ( 4 species of 4 genera), calcified cyanobacterias ( 3 species of 3 genera), chaetetids ( 1 species of 1 genus) and worms ( 1 species of 1 genus). The order of abundance of reef organisms is stromatoporoids, tabulate corals and chaetetids, 
followed by rugose corals and brachiopods, while bryozoans, calcified cyanobacterias and tubeworms are relatively scarce.

2. The Jiwozhai patch reef is characterized by coverstones as the main type of reef frame, containing rich laminar and encrusting-behaviour stromatoporoids and chaetetids, and laminar tabulate corals. Abundant massive and branching tabulate corals and solitary rugose corals are the main organisms to form framestones and bafflestones that fill the spaces between the coverstones. Reef dwellers including brachiopods, ostracods, bryozoans, gastropods, nautiloids, calcified cyanobacteria and tubeworms, which add to the reef biodiversity, but they are relatively scarce and not significant in forming the patch reef. The distribution of reef-frame builders is quite even, but significant variations occur among the surbordinate reef builder and reef dwellers. In the Jiwozhai patch reef the major reefframer building organisms form a group, here recognised as the Actiniostroma-ClathrocoilonaThamnopora-Crassialveolites ecological community.

3. Consistent with the densely packed and highly diverse species at Jiwozhai, complex ecological relationships, including extensive encrustation, spatial competition, and symbiosis have also been found among different organisms. The ecological relationships between the reef organisms are important for the formation of the patch reef.

4. Compared with the previously reported reefs in South China, the Jiwozhai patch reef, which is located in the platform interior, has a higher species diversity, indicating a biodiversity hotspot for the reef organisms, and is evidence that platform interiors are favourable places for reef growth. Coralstromatoporoid reefs are widespread globally in Givetian times, and growth forms vary according to different depositional environments. The reef-frame builders of laminar and encrusting-behaviour stromatoporoids and tabulate corals, with extensive biotic interactions, are a common feature found in many other reefs as well.

\section{Acknowledgments}

We sincerely thank two anonymous reviewers and editor Thoms Algeo for their constructive comments and suggestions. This work is financially supported by the Strategic Priority Research Program (B) of Chinese Academy of Sciences (XDB26000000), National Natural Science Foundation of China (grant Nos. 41772004, 41802002) and Geological Survey projects of China geological survey (No. DD20201121, 12120113063200).

\section{References}

Birenheide, R., Liao, W.H., 1985. Rugose Korallen aus dem Givetium von Dushan, Provinz Guizhou, S-China. 3: Einzelkorallen und einige Koloniebildner. Senckenb. Lethaea 66, 217-267.

Burchette, T.P., 1981. European Devonian reefs: A review of current concepts and models. Soc. Econ. Pa. 30, 85-142.

Chen, X., Zhang, Y.D., Fan, J.X., Cheng, J.F., Li, Q.J., 2010. Ordovician graptolite-bearing strata in southern Jiangxi with a special reference to the Kwangsian Orogeny. Sci. China Earth Sci. 53, 16021610.

Copper, P., 2002. Silurian and Devonian reefs: 80 million years of global greenhouse between two ice ages. In: Kiessling, W., Flügel, E., Golonka, J. (Eds.), Phanerozoic Reef Patterns. SEPM Special Publication No. 72, Tulsa, Oklahoma, 181-238.

Copper, P., Scotese, C.R., 2003. Megareefs in Middle Devonian supergreenhouse climates. Geological Soc. America Special Paper 370, 209-230.

Cook, A.G., 1999. Stromatoporoid palaeoecology and systematics from the Middle Devonian Fanning River Group, north Queensland. Mem. Queensl. Mus. 43, 463-551.

Dong, D.Y., Wang, S.B., Zhou, H.L., Zhang, Z.X., Luo, Q.H., Fu, J.H., Huang, T.Y., 1989. Devonian stromatoporoid biota of northern Guangxi and mountlike superimposed bioherm of Huanjiang county - with remarks on the distribution of the Devonian and sedimentary paleogeography in this area. Memoirs of Nanjing Institute of Geology and Palaeontology, Academia Sinica 26, 235-290 (in Chinese).

Dong, D.Y., Song, Y.F., 1992. Stromatoporoids from Devonian Chitzechiao (Qiziqiao) Formation of Jukoupu in Xinshao, Hunan and their reef-building characteristics. Acta Micropalaeontol. Sin. 9, 25-36 (in Chinese). 
Embry, A.F., Klovan, J.E., 1971. A late Devonian reef tract on northeastern Banks Island. N.W.T. Bull. Canadian Petrol. Geol. 19, 730-781.

Flügel, E., 2010. Microfacies of carbonate rocks: analysis, interpretation and application. second ed. Springer, Berlin, (984 pp.).

Fernandez-Martinez, E., Soto, F., Mendez-Bedia, I. 1994. An example of reef development in the Middle Devonian (Candas Fm., Givetian) in the Cantabrian Mountains (NW Spain). Cour. Forsch. Senck. 172, 103-110.

Geldsetzer, H.J., James, N.P., Tebbutt, G.E., 1989. Reefs: Canada and adjacent areas. Mem. Can. Soc. Petrol. Geol. 13, Calgary, (775 pp.)

Golonka, J., 2002. Plate-tectonic maps of the Phanerozoic. In: Kiessling, W., Flügel, E., Golonka, J. (Eds.), Phanerozoic Reef Patterns. SEPM Special Publication No. 72, Tulsa, Oklahoma, 21-75.

Hou, H. F, Wang, S. T., et al., 1988. Stratigraphy of China, No. 7: The Devonian System of China. Geological Publishing House, Beijing, 348 pp. (in Chinese).

Huang, J.Y., Liang, K., Wang, Y.J., Qie, W.k., 2019. Evolution of Devonian reefs and its influencing factors. J. Stratigraphy 43, 198-209 (in Chinese).

Hubert, B.L., Zapalski, M., Nicollin, J.P., Mistiaen, B., Brice, D., 2007. Selected benthic faunas from the Devonian of the Ardennes: an estimation of palaeobiodiversity. Acta Geol. Pol. 57, 223-262.

Jakubowicz, M., Król, J.J., Zapalski, M.K., Wrzołek, T., Wolniewicz, P., Berkowski, B., 2019. At the southern limits of the Devonian reef zone: palaeoecology of the Aferdou el Mrakib reef (Givetian, eastern Anti-Atlas, Morocco). Geological J. 54, 10-38.

Jin, S.Y., Ju, T.Y., 1998. Distribution Characteristics, Genesis and Reservoir Property of Sinian-Triassic Reefs in South China. Shanghai Scientific and Technical Press, Shanghai, 152 pp. (in Chinese).

Kershaw, S., Munnecke, A., Jarochowska, E., 2018 Understanding Palaeozoic stromatoporoid growth. Earth-Sci. Rev. 187, 53-76.

Kiessling, W., 2009. Geologic and biologic controls on the evolution of reefs. Annu. Rev. Ecol. Evol. S. 40, 173-192.

Kiessling, W., 2001. Paleoclimatic significance of Phanerozoic reefs. Geology 29, 751-754.

Kiessling, W., Flügel, E., Golonka, J., 2002, Phanerozoic Reef Patterns: SEPM Special Publication No. 72, Tulsa, Oklahoma, (775 pp.).

Liao, W.H., Xu, H.K., Wang, C.Y., Cai, C.Y., Ruan, Y.P., Mu, D.C., Lu, L.C., 1979. Discussion on several basic Devonian sections of Southwest China. In: Nanjing Institute of Geology and Palaeontology (Eds.), Carbonate biostratigraphy of Southwest China. Science Press, Beijing, pp. 221-249 (in Chinese).

Liao, W.H., Birenheide, R., 1984. Rugose Korallen aus dem Givetium von Dushan, Provinz Guizhou, S-China. 1: "Cystimorpha". Senckenb. Lethaea 65(1/3), 1-25.

Liao, W.H., Birenheide, R., 1985. Rugose Korallen aus dem Givetium von Dushan, Provinz Guizhou, S-China. 2: Kolonien der Columnariina. Senckenb. Lethaea 65(4/6), 265-295.

Liao, W.H., 2003. Devonian biostratigraphy of Dushan, southern Guizhou and its coral extinction events. Acta Palaeontol. Sin. 42, 417-427 (in Chinese).

Liu, J.R., Dong, D.Y., 1991. Middle Devonian stromatoporoids from mountlike superimposed bioherms along carbonate platform margin from Liuzhai, Nandan, Guangxi. Acta Micropalaeontol. Sin. 8, 309-324 (in Chinese).

Liu, L.J., Wu, Y.S., Jiang, H.X., Riding, R., 2016. Calcified rivulariaceans from the Ordovician of the Tarim Basin, Northwest China, Phanerozoic lagoonal examples, and possible controlling factors. Palaeogeogr, Palaeoclimatol, Palaeoecol 448, 371-381.

Liu, X.H., Liu, Z.H., Yang, M.D., Yang, R.F., Xiao, Y.J., Wang, Y., 2004. A preliminary study on the Devonian Buzhai reefs in Southern Guizhou. Chin. J. Geol. 39, $92-97$ (in Chinese).

Liu, Z.H., Yang, M.D., Liu, X.H., Yang, R.F., 2000. Comparative study on the Middle Devonian (Qiziqiao stage) biostromes in Hunan. Acta Palaeontol. Sin. 39, 279-284 (in Chinese).

Mao, Y.J., Wu, D.Y., 1995. Features of the Devonian reef in Maoying of Ziyun, Guizhou and its evolution. Guizhou Geol. 12, 307-310 (in Chinese).

May, A., 1988. Fossilführung und Palökologie des lagunären Massenkalkes (Devon) im Sauerland (Rheinisches Schiefergebirge). Paläontol. Z. 62, 175-192. 
May, A., 1991. Die Fossilführung des westsauerländischen Givetiums (Devon, Rheinisches Schiefergebirge) in der Sammlung des Städtischen Museums Menden. Geol. Palaeontol. Westfalen 17, 7-42.

May, A., 1992. Paleoecology of Upper Eifelian and Lower Givetian Coral Limestones in the Northwestern Sauerland (Devonian; Rhenish Massif). Facies 26, 103-116.

Mistiaen, B., 1985. Phénomènes récifaux dans le Dévonien d'Afghanistan. (MontagnesCentrales). Analyse et systématique des Stromatopores. Publication de la Société Géologique du Nord 11, vol. I: pp.381; vol. II: pp.245.

Playford, P.E., 1980. Devonian "Great Barrier Reef" of Canning Basin, Western Australia. AAPG Bull. 64, 814-840.

Qie, W.K., Ma, X.P., Xu, H.H., Qiao, L., Liang, K., Guo, W., Song, J.J., Chen, B., Lu, J.F., 2019. Devonian integrative stratigraphy and timescale of China. Sci. China Earth Sci. 62, 112-134.

Salerno, C., 2008. Stromatoporen-Fauna, Fazies und Paläoökologie von Plattformkarbonaten aus dem Unter-Givetium der Eifel (Devon, Rheinisches Schiefergebirge). Zitteliana B27, 3-129.

Scrutton, C.T., 1997. The Palaeozoic corals. I: origins and relationships. P. Yorks. Geol. Soc. 51, 177208.

Shen, J.W., Yu, C.M., 1996. Middle Devonian (Givetian) coral-stromatoporoid reef at Yanshan, north of Guilin, Guangxi, South China. Acta Palaeontol. Sin. 35, 686-701.

Song, Y.F., Zhang, Y.L., Liu, J.R., 1994. Community ecology of Middle Devonian (Qiziqiao time) organic reef from Jukoupu, Xinshao, Hunan. Acta Palaeontol. Sin. 33, 739-755 (in Chinese).

Stadelmaier, M., Nose, M., May, A., Salerno, C., Schröder, S., Leinfelder, R.R., 2005. Ästige tabulate Korallen-Gemeinschaften aus dem Mitteldevon der Sötenicher Mulde (Eifel): Faunenzusammensetzung und fazielles Umfeld. Zitteliana B 25, 5-38.

Stearn, C.W., 2015. Diversity trends of the paleozoic stromatoporoidea. In: Selden, P.A. (Ed.), Treatise on Invertebrate Paleontology, Part E (Revised), Porifera, Volume 5, Lawrence, Kansas, The University of Kansas Paleontological Institute, 593-597.

Tapanila, L., 2005. Palaeoecology and diversity of endosymbionts in Palaeozoic marine invertebrates: trace fossil evidence. Lethaia 38, 89-99.

Vinn, O., 2016. Symbiotic endobionts in Paleozoic stromatoporoids. Palaeogeogr, Palaeoclimatol, Palaeoecol 453, 146-153.

Vinn, O., 2017. Symbiosis between Devonian corals and other invertebrates. Palaios 32, 382-387.

Vopni, L.K., Lerbekmo, J.F., 1972. Sedimentology and Ecology of the Horn Plateau Formation: A Middle Devonian coral reef, Northwest Territories, Canada. Geol. Rundsch. 61, 626-646.

Wang, Y., 2016. The organic reef developed in the lower Jiwozhai Formation of the Middle Devonian in Dushan, southern Guizhou, China (Unpublished M.Sc. thesis). Beijing, China University of Geosciences. 49 pp. (in Chinese).

Wang, Y., Wang, X.L., Zhang, H.J., Jing, X.C., Sun, X., 2014. Contemporaneous slump structures in the Middle Devonian reef from Dushan, Guizhou and its geological siginificances. Geoscience 28, 265-270 (in Chinese).

Wood, A., 1948. "Sphaerocodium", a misinterpreted fossil from the Wenlock Limestone. P. Geologist Assoc. 59, 9-22.

Wu, Y.B., Gong, Y.M., Zhang, L.J., Feng, Q., 2010. Evolution and controlling factors of the Devonian bioreefs in South China. J. Palaeogeogr. 12, 253-267 (in Chinese).

Xian, H., Zhang, S., Li, H., Xiao, Q., Chang, L., Yang, T., Wu, H., 2019. How did South China connect to and separate from Gondwana? New paleomagnetic constraints from the Middle Devonian red beds in South China. Geophys. Res. Lett. 46, 7371-7378.

Yang, J.Z., Dong D.Y., 1963. Stromatoporoids from the Jiwozhai member, upper part of the Middle Devonian of Dushan District, Guizhou (Kueichow). Acta Palaeontol. Sin. 11, 147-177 (in Chinese).

Zapalski, M.K., Hubert, B.L., Nicollin, J., Mistiaen, B., Brice, D., 2007. The palaeobiodiversity of stromatoporoids, tabulates and brachiopods in the Devonian of the Ardennes -Changes through time. B. Soc. Geol. Fr. 178, 383-390.

Zapalski, M.K., Hubert, B.L.M., 2011. First fossil record of parasitism in Devonian calcareous sponges (stromatoporoids). Parasitology 138, 132-138. 
Zapalski, M.K., Wrzołek, T., Skompski, S., Berkowski, B., 2017. Deep in shadows, deep in time: the oldest mesophotic coral ecosystems from the Devonian of the Holy Cross Mountains (Poland). Coral Reefs 36, 847-860.

Zatoń, M., Jarochowska, M., 2018. Enigmatic encrusting fossils from the Upper Devonian of Russia: probable Rothpletzella microproblematica preserved in three dimensions. Hist. Biol. 1-11.

Zhen, Y.Y., West, R.R., 1997. Symbionts in a stromatoporoid-chaetetid association from the Middle Devonian Burdekin Basin, north Queensland. Alcheringa 21, 271-280.

\section{Table and Figure captions}

Table 1.35 cases of spatial competition between the reef organisms.

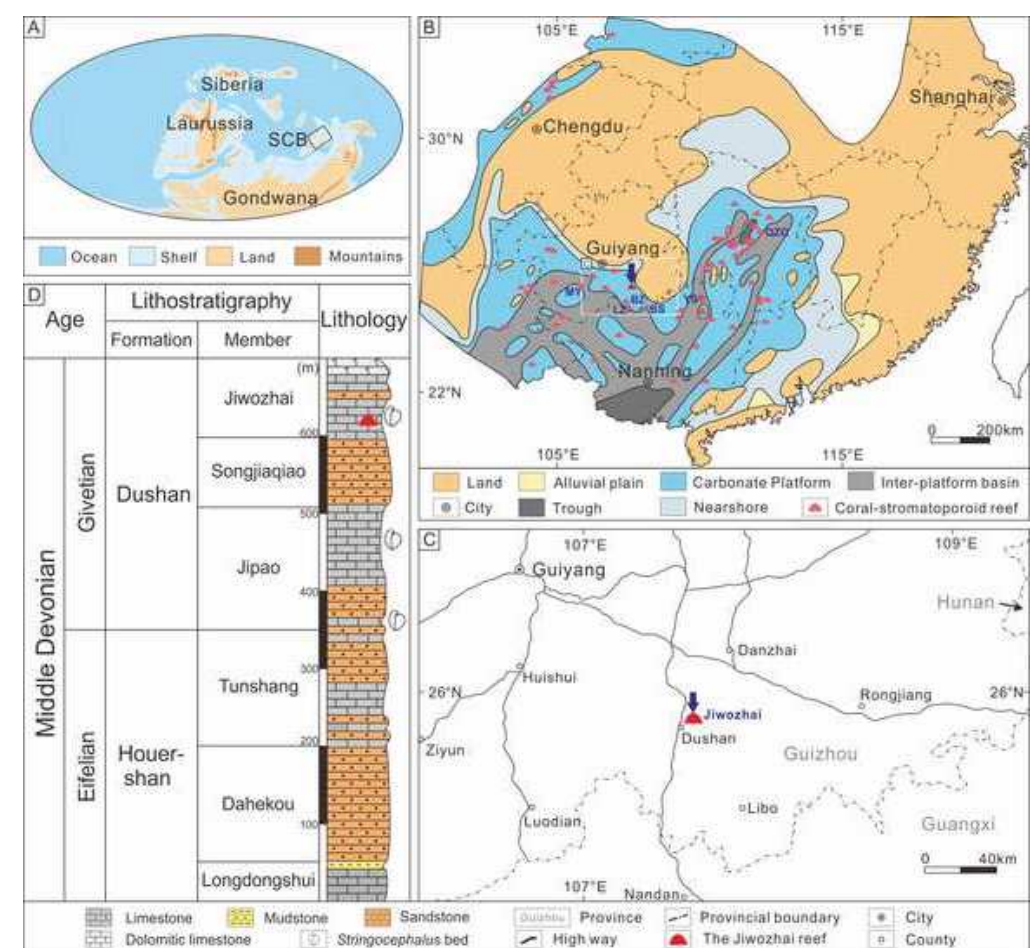

Fig. 1. (A) Global palaeogeography during the Givetian Epoch (Middle Devonian) (After Golonka, 2002), with a black rectangle indicating the South China Craton. (B) Palaeogeography of South China Block during the Givetian Epoch (modified after Jin and Ju, 1998), with red symbols marking the previously reported Givetian reefs in South China Craton (modified after Wu et al., 2010). Maoying reef (MY), Buzhai reef (BZ), Liuzhai reef (LZ), Beishan reef (BS) and Yanshan reef (YS) are noted in this study. (C) Map of the studied area, with a red symbol showing the location of the Jiwozhai reefs. (D) Middle Devonian stratigraphic framework of Dushan County, Guizhou, South China (After Liao et al., 1979; Liao, 2003). 


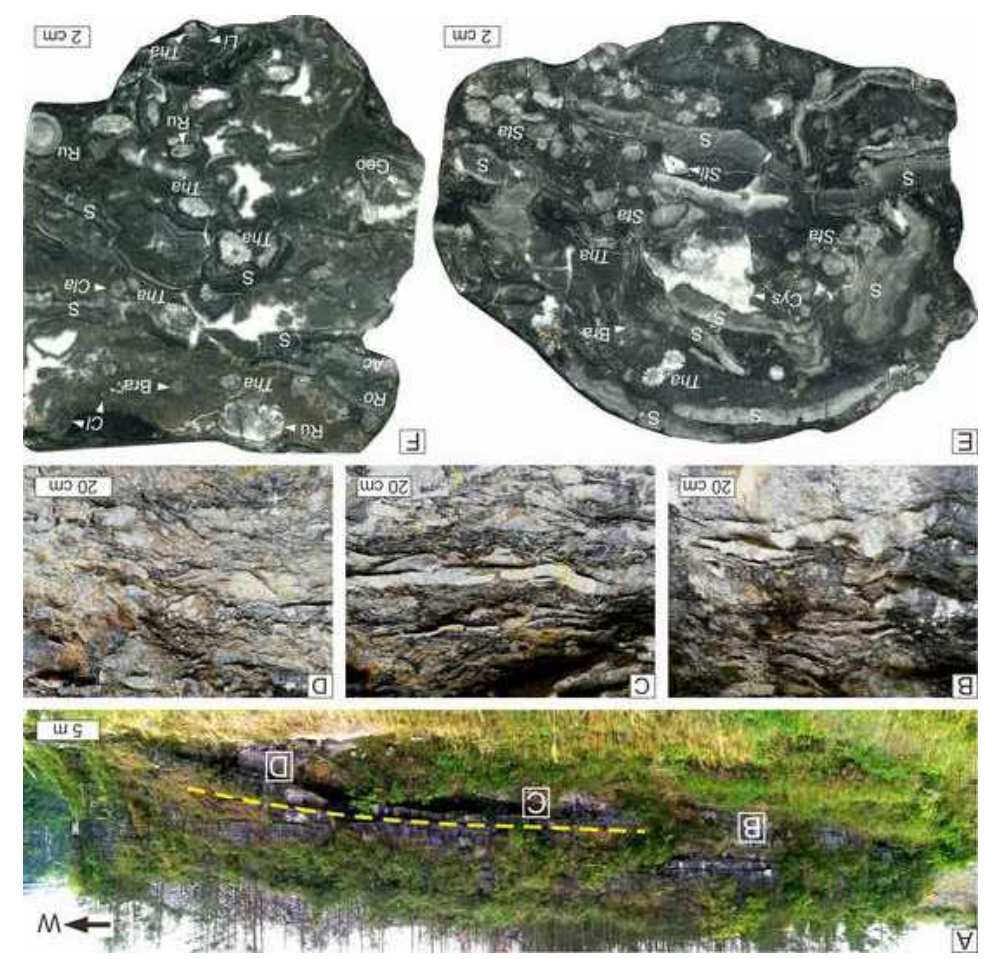

Fig. 2. Field photographs and polished slabs of the Jiwozhai patch reefs. (A) A general view of the patch reef (dash line) and the overlying beddings. (B-D) Enlarged field photos of the patch reefs in (A), showing the reef boundstones composed of coverstones, framestones, and bafflestones, note the densly packed reef organisms. (E, F) Polished slabs showing the contents of the coverstone, note laminar stromatoporoids encrusting rugose coral Cystiphylloides in (E) and the tabulate coral Thamnopora in (F). Ac: Actinotroma, Sti: Stictostroma, Sta: Stachyodes, Cys: Cystiphylloides, Tha: Thamnopora, Cla: Clathrocoilona, Cl: Cladopora, Ro: Roseoporella, Li: Litophyllum, Ru: rugose coral, S: stromatoporoids, Bra: unknown brachiopod, Geo: geopetal sturcture. 

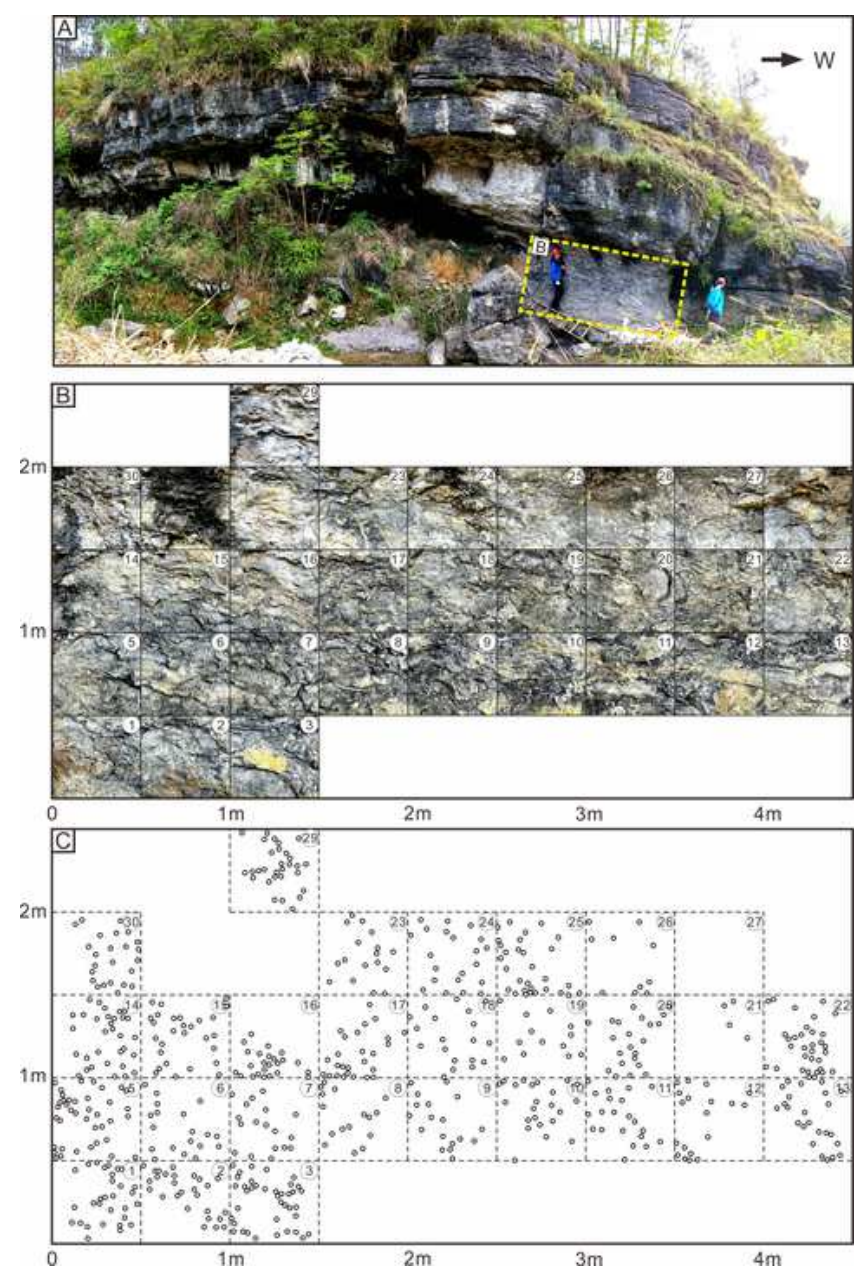

678 Fig. 3. Field photographs and division of the quadrats in the studied patch reef, with divisions of the 28 679 quadrats. (A) A general view of the patch reef, with a yellow rectangle showing the studied patch reef. 680 (B) Enlarged field photo of the rectangular area in (A), showing the divisions of the quadrats. (C) 

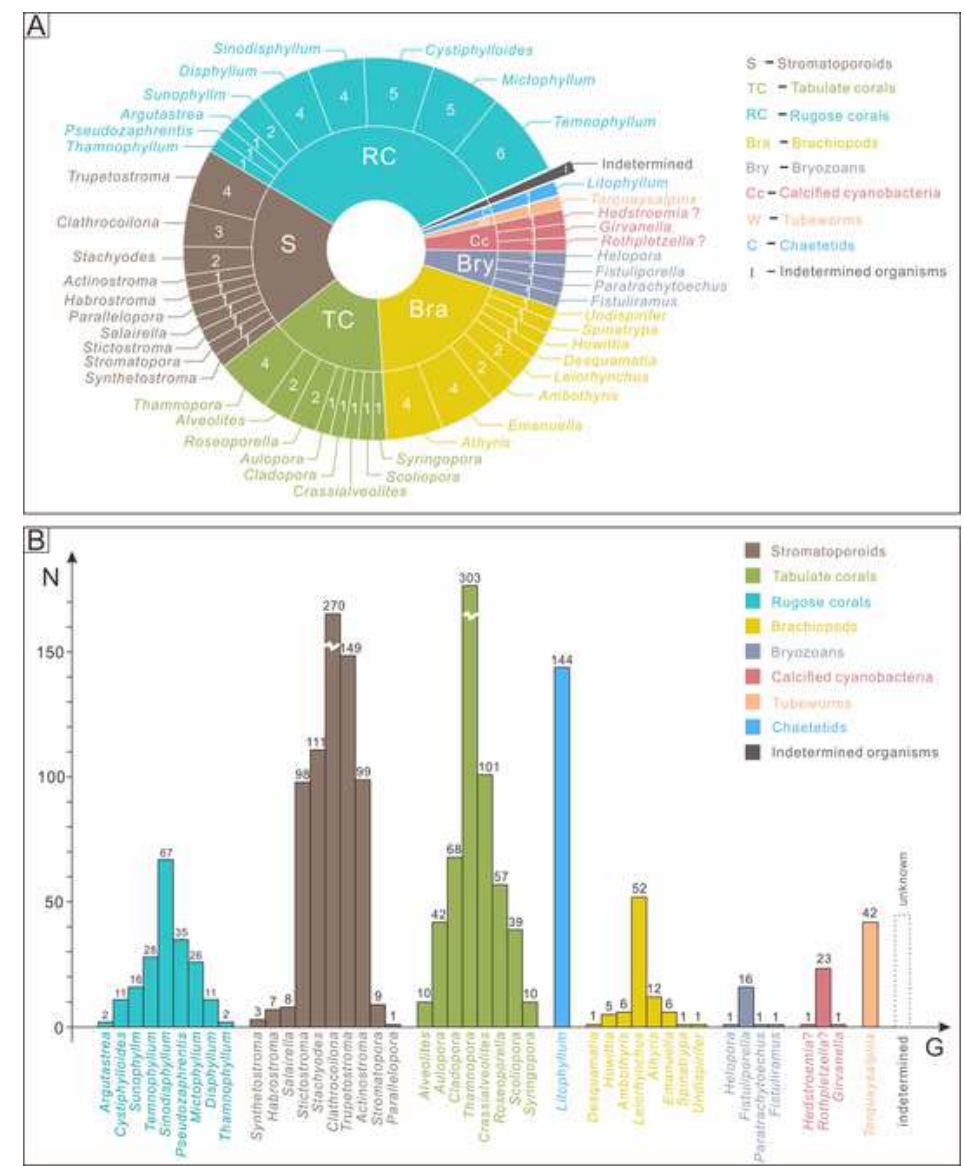

Fig. 4. (A) Diversity of reef organisms in the studied Jiwozhai reef, with numbers indicating species richness, and percentages showing the abundance of species among the reef organisms. (B) Distribution 


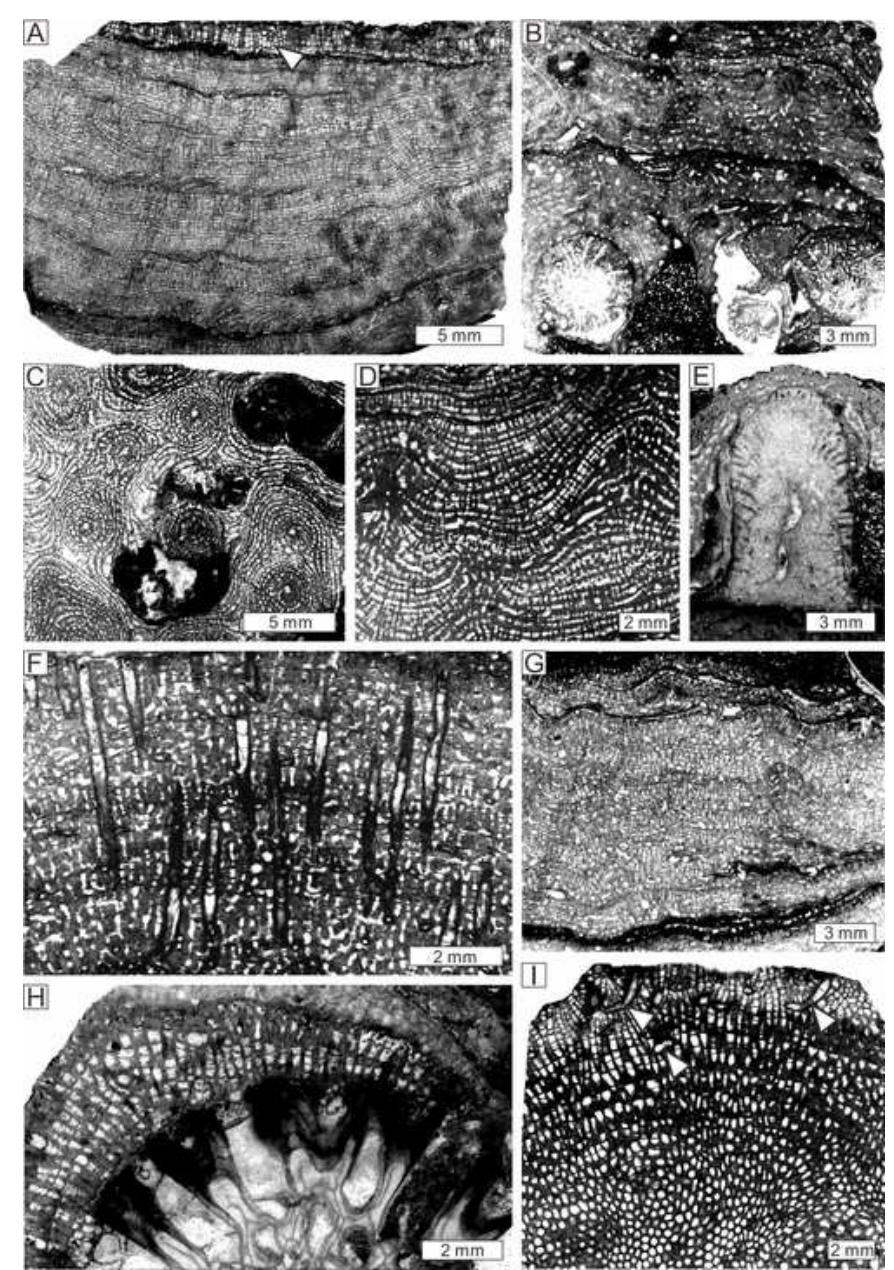

Fig. 5. Stromatoporoids and chaetetids in the studied Jiwozhai patch reef. (A) Longitudinal section showing Actinostroma undulatum, with a white arrow indicating the superposition of chaetetid Litophyllum inflatus, note the presence of latilaminae in the stromatoporoid. (B) Clathrocoilona spissa encrusting tabulate coral Scoliopora, note the presence of latilaminae in the stromatoporoid. (C) Transverse sections showing stromatoporoid Stictostroma saginatum. (D) Longitudinal section showing stromatoporoid Synthetostroma actinostromoides. (E) Stromatoporoid Stachyodes costulata encrusted by stromatoporoid Stictostroma saginatum, note the attachment of tabulate coral Aulopora cf. compacta. (F) Endosymbiotic Syringopora inside the skeleton of stromatoporoid Stromatopora hüpschii. (G) Longitudinal section of Trupetostroma dushanense, note the presence of latilaminae. $(\mathrm{H})$ Chaetetid Litophyllum inflatus encrusting tabulate coral Thamnopora compacta. (I) Endosymbitoic tubeworms (white arrows) within Litophyllum inflatus. 

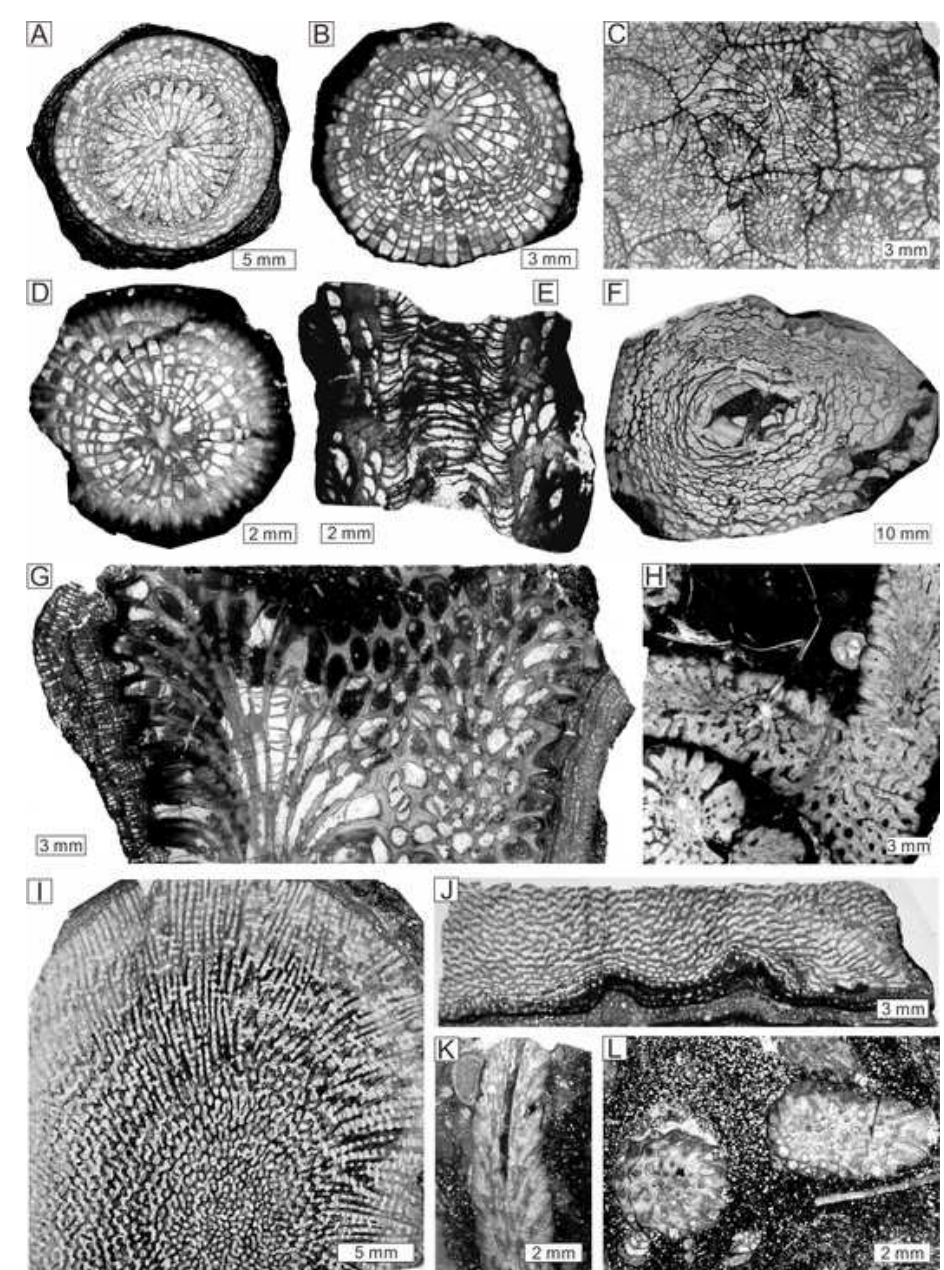

Fig. 6. Common rugose and tabulate corals in the Jiwozhai patch reef. (A) Transverse section showing solitary rugose coral Pseudozaphrentis hejiazhaiense encrusted by stromatoporoid Clathrocoilona crassitexta. (B) Transverse section showing solitary rugose coral Sinodisphyllum simplex. (C) Transverse sections showing cerioid rugose coral Argustarea thomasi. (D) Transverse sections showing solitary rugose coral Sunophyllum typicum. (E) Longitudinal section of solitary rugose coral Sunophyllum typicum. (F) Transverse section showing solitary rugose coral Cystiphylloides corneolum. (G) Tabulate corals Thamnopora compacta encrusted by chaetetid Litophyllum inflatus (left) and stromatoporoid Clathrocoilona (right). (H) Branching tabulate coral Thamnopora cf. pansiensis. (I) Domical tabulate coral Crassialveolites dushanensis. (J) Laminar tabulate coral Alveolites fornicatus grow on the skeletons of stromatoporoid Clathrocoilona. (K) Longitudinal view of branching tabulate coral Cladopora fistula. (L) Transverse section of Cladopora fistula. 

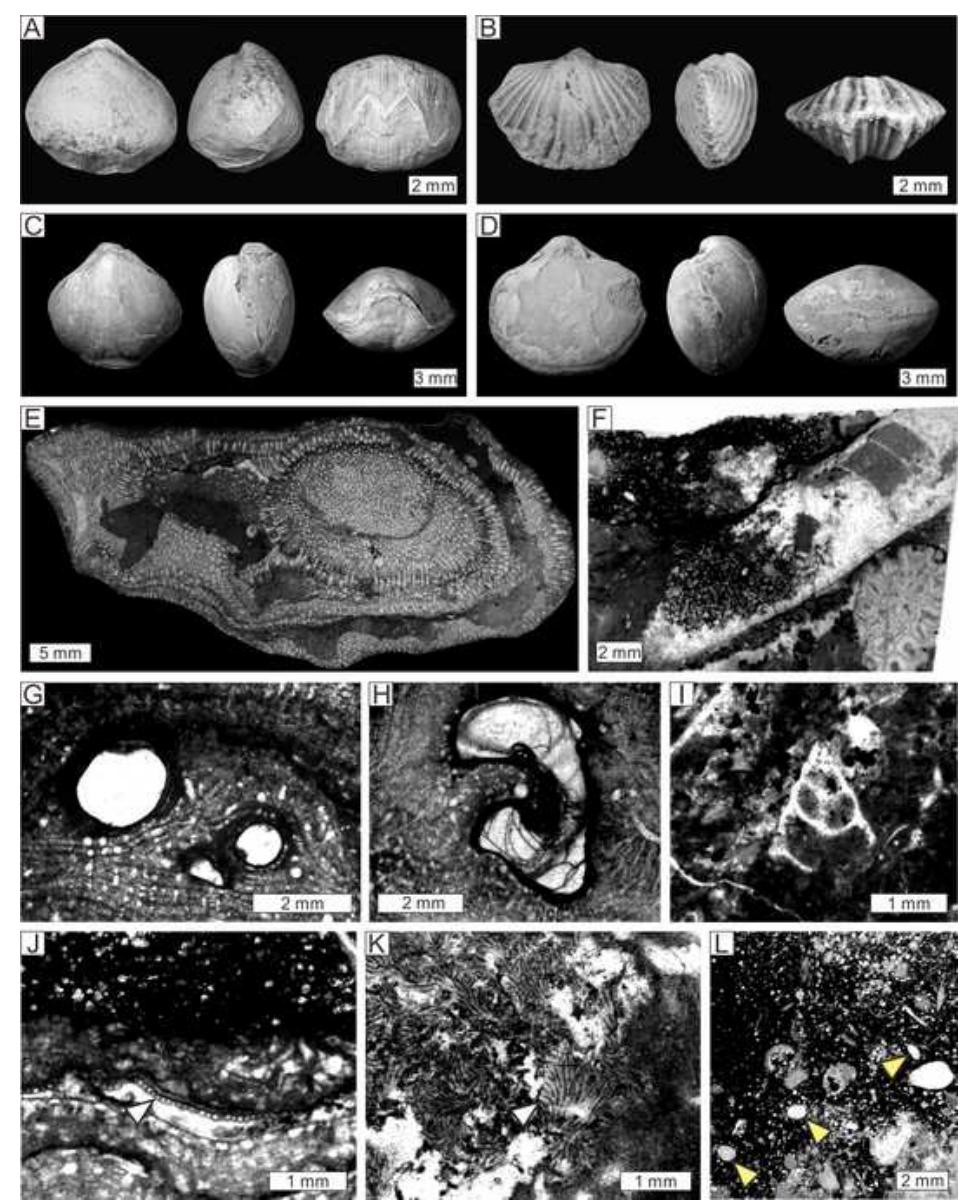

Fig. 7. Reef dwellers in the studied Jiwozhai patch reef. (A) Brachiopod Leiorhychus sp. A, showing dorsal, lateral and anterior views from left to right. (B) Brachiopod Howittia dushanensis, showing dorsal, lateral and anterior views from left to right. (C) Brachiopod Athyris sp. A, showing dorsal, lateral and anterior views from left to right. (D) Brachiopod Emanuella plicata, showing dorsal, lateral and anterior views from left to right. (E) Bryozoan Fistuliramus sp. (F) Nautiloid of unknown species. (G) Longitudinal section showing tubeworm Torquaysalpinx sokolovi within the stromatoporoid Trupetostroma dushanense. (H) Tubeworm Torquaysalpinx sokolovi within the skeleton of stromatoporoid Trupetostroma dushanense, note the present of dissepiments inside the tube. (I) A small gastropod of unknown species. (J) Calcified cyanobacteria Rothpletzella? (K) Transverse view of another calcimicrobe, possibly Hedstroemia?, with a white arrow showing the continuously bifurcated 


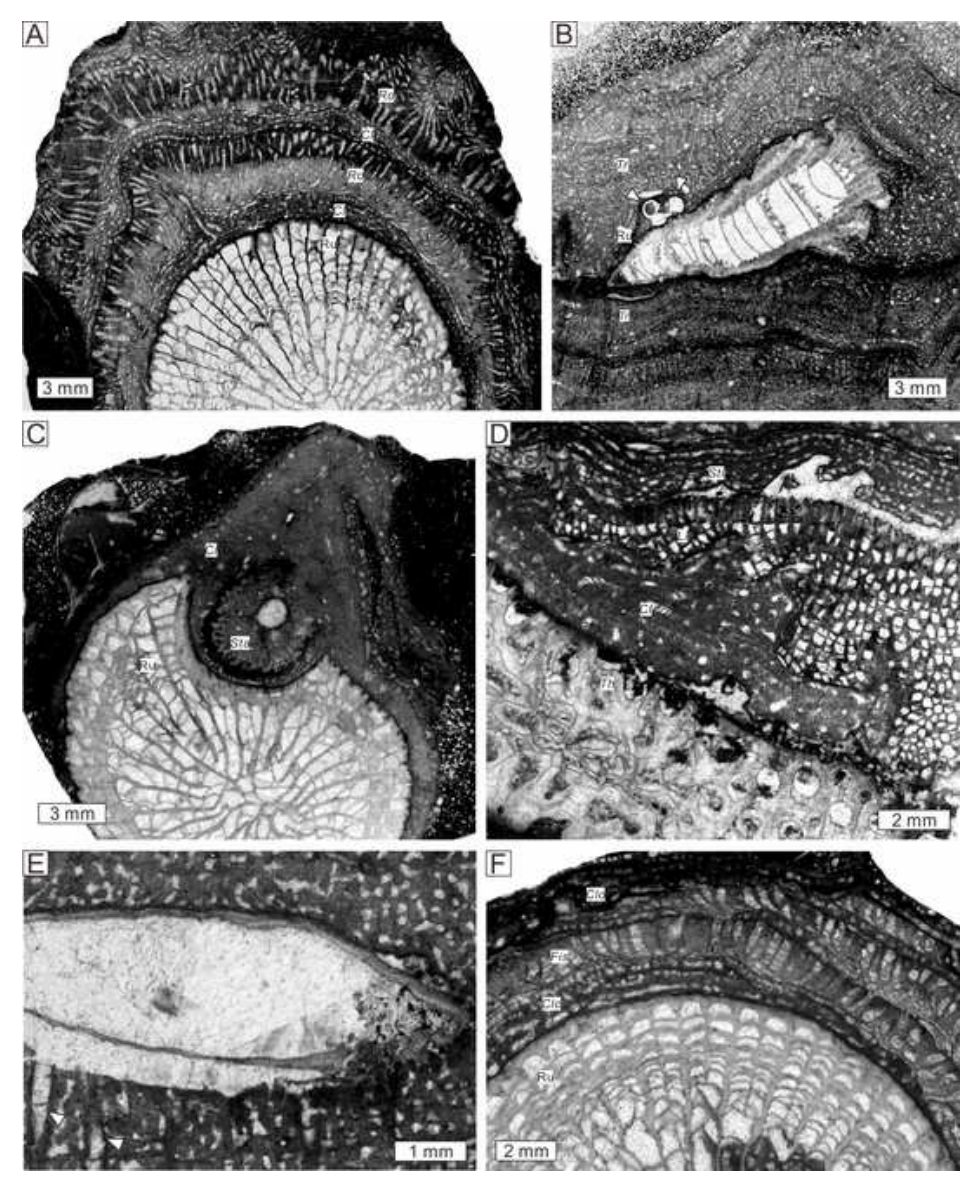

Fig. 8. Biotic interactions among the reef organisms in the studied Jiwozhai patch reef. (A) Alternations of encrusting stromatoporoid Clathrocoilona $(\mathrm{Cl})$ and tabulate coral Roseoporella $(\mathrm{Ro})$ over a solitary rugose coral $(\mathrm{Ru})$, forming a growth sequence of multiple encrustations. (B) A solitary rugose coral $(\mathrm{Ru})$ that grew on the skeleton of stromatoporoid Trupetostroma $(\mathrm{Tr})$ was encrusted by another skeleton of Trupetostroma (Tr), note unknown shells attached on the rugose coral (arrows). (C) Syn-vivo interactions between stromatoporoid Clathrocoilona $(\mathrm{Cl})$ and a solitary rugose coral $(\mathrm{Ru})$, note the irregular shape of the corallum and a possible dead skeleton of stromatoporoid Stachyodes (Sta) inside the skeleton of Clathrocoilona. (D) Spatial competition between stromatoporoid Clathrocoilona $(\mathrm{Cl})$ and chaetetid Litophyllum inflatus ( $(\mathrm{i})$, showing interfinger-marginal contacts, note the hard substrate provided by a possible dead skeleton of tabulate coral Thamnopora (Th). (E) Brachiopod shells embedded inside the stromatoporoid Stromatopora (St) skeleton, note endosymbiotic tabulate coral Syringopora below (arrows). (F) Complex encrustations between stromatoporoid Clathrocoilona crassitexta (Clc), Clathrocoilona obliterata (Clo), and bryozoan Fistuliporella hemispheroidea (Fis) over rugose coral Sinodisphyllum $(\mathrm{Ru})$, forming a growth sequence. 


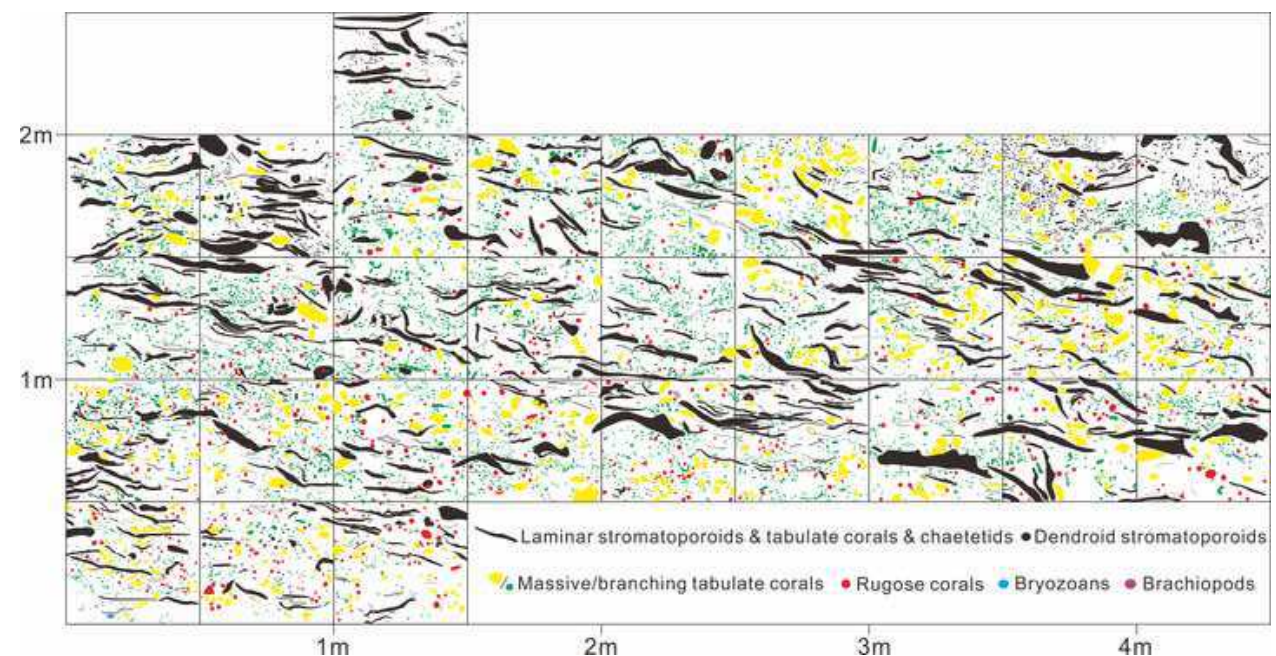

Fig. 9. Vertical section of the quadrat area of the Jiwozhai patch reef, showing distribution of reef organisms, based on extensive sampling and field photos of the 28 quadrats.

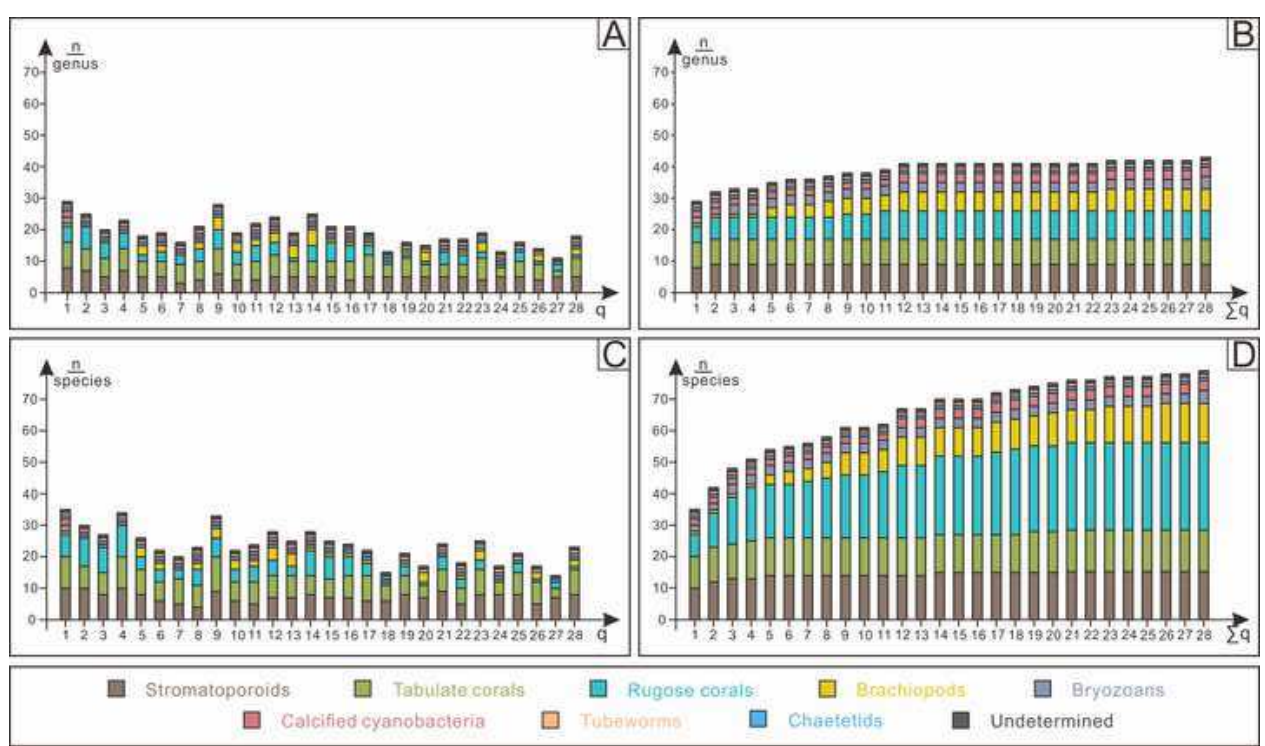

Fig. 10. (A) Generic level occurrences of the reef organisms in each quadrat of the Jiwozhai reef. (B) The accumulation of generic level occurrences of reef organisms from the first quadrat to the last. (C) Specific level occurrences of reef organisms each quadrat of the Jiwozhai reef. (D) The accumulation of specific level occurrences of reef organisms from the first quadrat to the last. 